Australia

\section{Lay head for CSIRO board}

\section{Sydney}

THE initial reaction of the Australian scientific community to the appointment of former New South Wales Premier and federal president of the Australian Labour Party (ALP), Mr Neville Wran, as head of Australia's largest research body, the Commonwealth Scientific and Indust-

\section{Britain gets Cray supercomputer at last...}

ThE UK Science and Engineering Research Council (SERC) has at last taken delivery of its Cray X-MP/48 supercomputer, after much discussion between the British Department of Trade and Industry and the US Department of Commerce.

For months, the latter has been concerned that 'foreign aliens' might gain easy access to the supercomputer which is to be housed at the Rutherford Appleton Laboratory. The Americans wished to impose rigid restrictions on $\mathrm{SERC}$, a move vigorously resisted by the British authorities.

For logistic reasons, trade officials from both sides of the Atlantic had been unable to meet to discuss the subject, so the Americans have approved the purchase to prevent any further delay but without receiving the assurances they originally sought. The trade authorities will meet soon to discuss the 'principles' of the case. The rial Research Organization (CSIRO), lay somewhere between surprise and shock. The parliamentary opposition described the appointment as "appalling political cronyism". Many CSIRO scientists were dismayed by Wran's appointment, which marks the end of a 60 -year tradition of having a scientist at the head of CSIRO, but this feeling seems to have given way to guarded optimism that Wran's undoubted political acumen and extensive connections with industry will be great assets.

Wran was premier of New South Wales for 10 years and federal president of ALP for 6 until his surprise resignation from both positions last July. His government would not have had to face another election until early 1988 . The stated reason for his resignation was that he was tired of politics and that stepping out mid-term would give his successor time to get used to the reins of government before having to face an election.

Wran's appointment coincides with the disclosure of legislation designed to give CSIRO a new board and structure. The changes are the result of recommendations by an Australian Science and Technology Council review of the organization's operation. In the new board, policymaking and management functions have been separated to make it more like the board of a normal corporate body. The old board consisted of three full-time members, all distinguished scientists, and five part-time outside members. One of the full-time members was chairman and chief executive, a position held in the last board by Dr Keith Boardman. In the new model these posts have been split, with the chief executive becoming the only fulltime member of a 10 -man board. The chief exccutive is thus the most senior CSIRO scientist. Boardman has been appointed permanently as chief executive subject to the approval of the board which is due to meet for the first time this month.

It will be the task of the new board to align CSIRO's research ambitions with national priorities, which means increasing emphasis on industrially applicable rescarch, particularly on that applicable to manufacturing, although Boardman is careful to point out that this does not mean a diminution in cither the quantity or quality of fundamental and rural research carried out by CSIRO. In fact, the number of scientists working in rural research has increased because of more funding from outside sources despite the decreases in government money.

In addition to Wran, the part-time board members include two scientists, a farmer, a representative from the union movement and four representatives from industry, so it should be well suited to its task of linking CSIRO to the strategic needs of industry.

The Minister for Science, Mr Barry Jones, has long bemoaned the poor record of scientists for standing up in public and speaking out for their own cause, and has even gone so far as to call them "wimps". Perhaps the appointment of a politician to head CSIRO means that Jones has concluded that the best way to get the scientists' case heard is to give them a voice to speak for them.

Charles Morgan 